\author{
I. Momot ${ }^{1}$, O. Kovalchuk ${ }^{1}$, O. Okhrimenko ${ }^{1}$, Y. Prezado' ${ }^{2}$, V. Pugatch ${ }^{1}$ \\ ${ }^{1}$ Institute for Nuclear Research, National Academy of Sciences of Ukraine, Kyiv, Ukraine \\ ${ }^{2}$ Laboratoire d'Imagerie et Modélisation en Neurobiologie et Cancérologie (IMNC, CNRS), Orsay, France
}

\title{
SHAPING AND MONITORING OF THE MINI-BEAM STRUCTURES FOR THE SPATIALLY FRACTIONATED HADRON RADIATION THERAPY
}

\begin{abstract}
Design of collimators and their effectiveness for the purposes of the fractionated mini-beam hadron radiation therapy were evaluated by Monte Carlo simulations. The calculations have been performed for proton, carbon and oxygen ion beams at the energies relevant for medical applications. Micropixel metal and hybrid detectors were tested for measuring charged particles intensity distribution in multi-beam structures shaped by slit or matrix collimators exploring low energy proton beam at the Tandem generator (INR NASU, Kyiv). The results obtained illustrate reliable performance of the designed collimators as well as hybrid and metal microdetectors for measuring and imaging in real time the proton intensity distribution over mini-beam structures.

Keywords: spatially fractionated hadron radiation therapy, beam collimators, Monte Carlo simulation of dose distribution, monitoring of spatial distribution of the intensity of the charged particle beams, micropixel metal and hybrid
\end{abstract} detectors.

\section{Introduction}

High energy (several hundred MeV/nucleon) heavy ion beams are considered as promising tool to provide better therapeutic results due to dose localization and high biological effectiveness in comparison to conventional X-ray radiotherapy [1 - 3]. Hadron therapy could benefit further from a lower impact on normal tissues if combined with established tissue-sparing effect of spatially fractionated beams, observed in biological studies performed with synchrotron radiation [4 - 6]. The conceptual advantages of Hadron Minibeam Radiation Therapy have been discussed elsewhere [7]. Monte Carlo simulations of dose distribution resulting from spatially fractionated irradiations have stimulated the interest of performing experiments in order to crosscheck these evaluations [8]. The dose profiles consist in peaks and valleys. High Peak-to-Valley Dose Ratios (PVDR) values and low valleys are required for normal tissue preservation, while low PVDR or homogeneous distribution is searched for in the target. Monitoring of the hadrons fluence distribution over the multi-beam structure is of a paramount importance for determination of the micro dose distribution delivered to tissue. Gafchromic films is one of the few detectors able to provide the spatial resolution needed in these techniques [9 - 11]. Their offline analysis provides excellent position accuracy (few micrometers) of the dose distribution. Yet, it is a time consuming procedure and it is impossible to have an online dose monitoring.

There are studies related to application of microdetectors with a few micrometer position resolution for the micro-dose distribution assessment [12, 13]. In particular, metal ones have demonstrated reliable operation in real time at high radiation loads [14]. In case of high energy hadron therapy both types of above mentioned detectors do not provide directly the measurement of the dose delivered to tissue. One has to take into account the impact of secondary particles on the dose formation, their biological efficiency. Studies undertaken in works [15 - 18] indicate the fact that major part of the dose is delivered by the primary beam particles.

In this paper, the results of studies for two different techniques are described: minibeam and grid radiation therapy. The studies were undertaken in view of forthcoming feasibility studies at Heidelberger Ionenstrahl-Therapiezentrum (HIT) (Heidelberg) related to the design of collimators and their effectiveness for the purposes of the Fractionated Hadron Radiation Therapy (FHRT). Monte Carlo simulations for the proton, carbon and oxygen ion beams at the energies relevant for medical applications are presented along with the test data obtained with low energy protons at the KINR Tandem generator (INR NASU, Kyiv) exploring micropixel metal and hybrid detectors for measuring charged particles intensity distribution in multi-beam structures shaped by slit or matrix collimators. The results obtained illustrate reliable performance of the designed collimators as well as of the hybrid and metal microdetectors for measuring and imaging in real time the ions flux distribution over multi-beam structures.

\section{Monte Carlo Simulations for the fractionated hadron radiation therapy}

Monte Carlo simulations of dose distribution resulting from spatially fractionated irradiations have been performed to optimize the characteristics of the experimental setup for carrying out feasibility studies. 
Design of collimators and their effectiveness were evaluated by Monte Carlo simulations in the framework of a software package for medical physics «Gate_v.6.2» based on Geant4 version [19, 20]. Ideal rectangular ( $0.7 \mathrm{~mm}$ wide) beam of protons with angular spreading of Gaussian shape was assumed passing through water phantom of cylindrical shape with $16 \mathrm{~cm}$ height and $16 \mathrm{~cm}$ diameter. Beam divergence of $3 \mathrm{mrad}$ for $\mathrm{X}$ - and $\mathrm{Y}$-coordinates was considered. Dose was calculated for voxels with the size of $(0.01 \times 1 \times 1) \mathrm{mm}^{3}$ in each fractional part as the sum of the contributions from every individual minibeam to cover required irradiation field. The ionization potential for water was assumed to be $75 \mathrm{eV}$ (as recommended in [20, 21]). As figure of merit, percentage (peak and valley) depth dose curves, penumbras, and central value of the PVDR have been calculated for various collimators, incident ions and their energies. The PVDR depends on the collimator material, ratio of width/pitch (w/p) for slit collimators, on the distance between collimator and phantom. The major factor is evolution of PVDR over the depth in phantom. It was pointed out in [7], that one would expect the best results from mini-beam fractionated therapy

Dose, a. u.

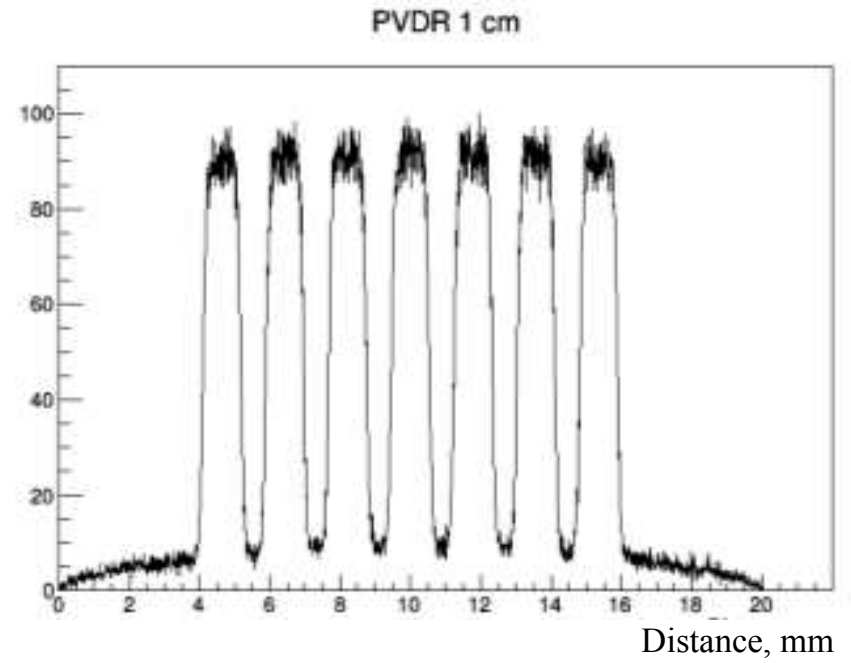

in case of such shaping of beams that PVDR produced on their way to the tumor are largest in the healthy tissue, while fractionation degrades at the depth of the tumor. The scattering of protons by the slit/holes edges as well as the contamination by the secondary products generated in the collimators makes also fractionation less pronounced. The goal is to find out optimal technical features of the collimators as well as micro-detectors measuring spatial distribution with adequate resolution.

To illustrate a possibility to find such features of the experimental setup we present some examples of simulations performed for the proton beam energy of $87 \mathrm{MeV}$ allowing to reach target (tumor) at the depth around $5 \mathrm{~cm}$. Similar simulations were made for protons with energy $150 \mathrm{MeV}$, and ${ }^{12} \mathrm{C}$ and ${ }^{16} \mathrm{O}$ ions at 100 and $200 \mathrm{MeV} /$ nucleon which are of the practical medical interest in hadron therapy. Collimator thickness is determined by the range of ions in a specific material. From practical point of view collimators were supposed to be made out of brass (range: for $87 \mathrm{MeV}$ protons $-1.5 \mathrm{~cm}$; for $150 \mathrm{MeV}$ $-3.5 \mathrm{~cm}$ ) or aluminum (range: for $87 \mathrm{MeV}$ protons $3.5 \mathrm{~cm}$; for $150 \mathrm{MeV}-7.5 \mathrm{~cm}$ ). Proton beam field size was considered to be $(2 \times 2) \mathrm{cm}^{2}$.

Dose, a. u.

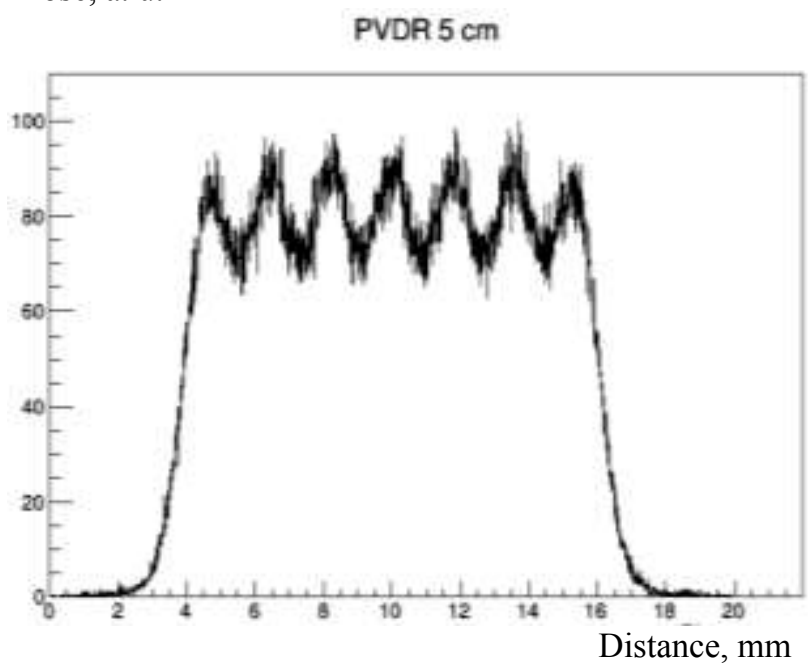

Fig. 1. Monte Carlo simulation for the lateral distribution of the dose delivered by $87 \mathrm{MeV}$ proton beam passing through the $7 \times 7$ holes (diameter $1 \mathrm{~mm})$ in a brass MATRIX collimator $(\mathrm{t}=1.5 \mathrm{~cm})$.

Fig. 1 shows the results of the Monte Carlo simulation for the dose profile (projection onto horizontal axis) delivered by the $87 \mathrm{MeV}$ proton beam passing through the MATRIX collimator: $7 \times 7$ holes with a diameter of $1 \mathrm{~mm}$ made in a $1.5 \mathrm{~cm}$ thick $(\mathrm{t}=1.5$ $\mathrm{cm})$ brass plate, with center-to-center (c-t-c) distance of $2.0 \mathrm{~mm}$. Left part of the Fig. 1 corresponds to the dose at the depth in a water phantom of $1 \mathrm{~cm}$, right $5 \mathrm{~cm}$. Distance between phantom and collimator $20 \mathrm{~cm}$. The digital results for the PVDR values at different depths in a phantom are presented in the Table 1 also for the MATRIX collimator made out of the aluminum plate (thickness $3.5 \mathrm{~cm}$ ). Table 2 shows results for the SLIT collimators (1 mm wide slits with a c-t-c distance of $2.0 \mathrm{~mm}$ ).

Table 1. PVDR (horizontal projection) for the MATRIX collimators at different depth in water phantom. Proton energy is $87 \mathrm{MeV}$

\begin{tabular}{|c|c|c|}
\hline $\begin{array}{c}\text { Depth } \\
\text { in phantom, cm }\end{array}$ & $\begin{array}{c}\text { Brass } \\
(\mathrm{t}=1.5 \mathrm{~cm}), \\
\text { PVDR }\end{array}$ & $\begin{array}{c}\text { Aluminum } \\
(\mathrm{t}=3.5 \mathrm{~cm}), \\
\text { PVDR }\end{array}$ \\
\hline 1 & $7.9 \pm 1$ & $3.2 \pm 0.4$ \\
\hline 2 & $5.3 \pm 0.2$ & $3.1 \pm 0.2$ \\
\hline 3 & $3.2 \pm 0.3$ & $2.5 \pm 0.1$ \\
\hline 4 & $2.1 \pm 0.2$ & $1.8 \pm 0.1$ \\
\hline 5 & $1.3 \pm 0.1$ & $1.2 \pm 0.1$ \\
\hline
\end{tabular}


Table 2. PVDR for the SLIT collimators at different depth in water phantom. Proton energy is $87 \mathrm{MeV}$

\begin{tabular}{|c|c|c|}
\hline $\begin{array}{c}\text { Depth } \\
\text { in phantom, cm }\end{array}$ & $\begin{array}{c}\text { Brass } \\
(\mathrm{t}=1.5 \mathrm{~cm}), \\
\text { PVDR }\end{array}$ & $\begin{array}{c}\text { Aluminum } \\
(\mathrm{t}=3.5 \mathrm{~cm}), \\
\text { PVDR }\end{array}$ \\
\hline 1 & $13.9 \pm 1.2$ & $6.0 \pm 0.7$ \\
\hline 2 & $10.8 \pm 1.1$ & $5.5 \pm 0.6$ \\
\hline 3 & $4.5 \pm 0.2$ & $3.6 \pm 0.2$ \\
\hline 4 & $2.2 \pm 0.1$ & $1.9 \pm 0.3$ \\
\hline 5 & $1.4 \pm 0.1$ & $1.3 \pm 0.1$ \\
\hline
\end{tabular}

From data presented in Fig. 1 as well as in the Tables 1 and 2 one may conclude that a brass collimators provide better results. The remarkable feature of the simulations is that for both collimator types high PVDR values are observed on the way from the surface to a target (tumor), while nearly homogeneous dose distribution is realized at the depth of the target (tumor) $-5 \mathrm{~cm}$, thus illustrating a possibility to realize this important additional advantageous feature of the hadron fractionated therapy [7].

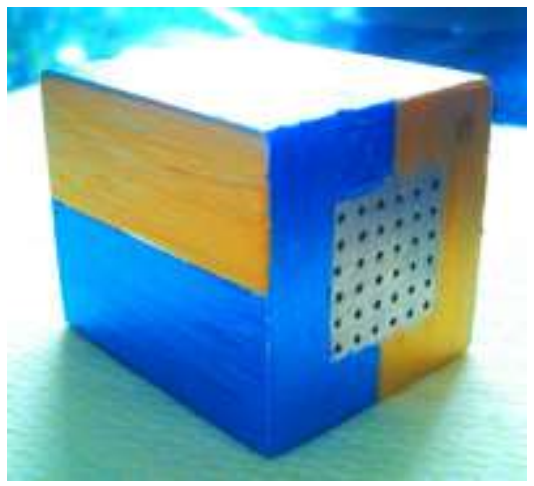

Fig. 2. Photo of the prototypes of the collimators for shaping mini-beam structures for the spatially fractionated hadron radiation therapy. See color Figure on journal website.

\section{Experimental tests at the KINR Tandem generator}

The first tests of the experimental setup for shaping and monitoring of the hadron beam for the purposes of the fractionated radiation therapy have been performed at the KINR Tandem Generator (Kyiv, Institute for Nuclear Research).

Collimators with slits ('SLIT', $1 \mathrm{~mm}$ width, 3 $\mathrm{mm}$ pitch) and holes ('MATRIX', $1 \mathrm{~mm}$ in diameter, $2 \mathrm{~mm}$ pitch) for shaping the proton beam were explored. Both were manufactured out of $2 \mathrm{~mm}$ thick Al plates and covered active area of the TimePix detector $\left(14 \times 14 \mathrm{~mm}^{2}\right)$ with 5 slits and $5 \times 5=25$ holes, correspondingly. Protons with the energy of $3 \mathrm{MeV}$ were incident on the polyethelene target installed inside the reaction chamber (Fig. 3).

There were two TimePix detectors positioned at $100 \mathrm{~mm}$ from the target center and 45 degrees from both sides of the proton beam. One of them was operated in a metal mode while another one in a
Calculations have been performed also for carbon-12 and oxygen-16 ions with energies of 100 and $200 \mathrm{MeV} /$ nucleon as well as for protons with energy $150 \mathrm{MeV}$. The results look very similar with the outcome that brass material is more suitable for the collimators production. Detailed digital values will be presented in the forthcoming paper, presenting also experimental results of the tests with these ions at the HIT (Heidelberg). Summarizing this part of studies we conclude that the use of hadrons has the advantage of delivering a nearly uniform dose distribution in the tumor, while healthy tissue benefits from the spatial fractionation of the dose.

For the tests at HIT (Heidelberg) several slit and matrix collimators were designed and produced at KINR, exploring the results of the above presented Monte Carlo simulations. Photos of some of them are shown in Fig. 2 (Left: Matrix collimator - aluminum, $3.5 \mathrm{~cm}$ thick; $(6 \times 6)$ holes with diameter of 1 $\mathrm{mm}, \mathrm{c}-\mathrm{t}-\mathrm{c}$ distance $-2.5 \mathrm{~mm}$. Right: Slit collimator brass, $3 \mathrm{~cm}$ thick, 6 slits with $1 \mathrm{~mm}$ width, c-t-c distance $2.5 \mathrm{~mm}$ ).
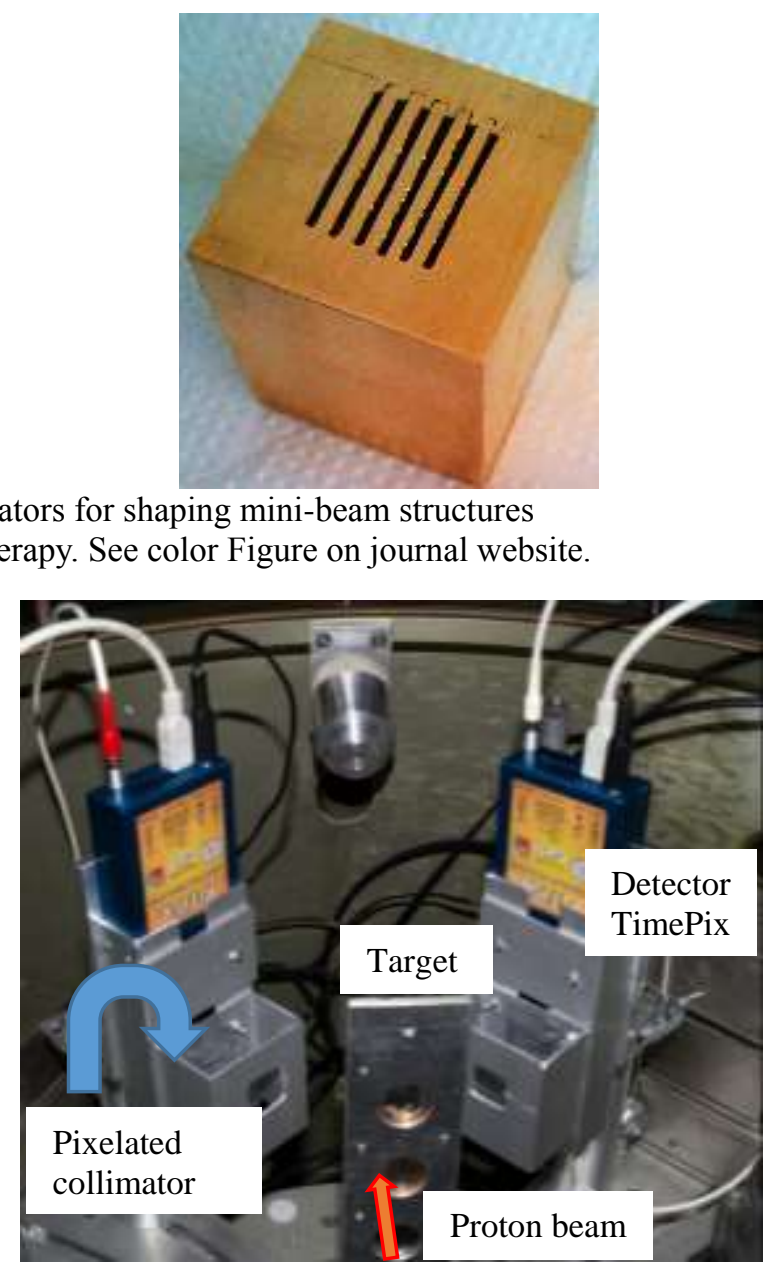

Fig. 3. Photo of the reaction chamber at the KINR Tandem generator with two TimePix detectors and matrix collimators in front of them. See color Figure on journal website.

hybrid mode with $300 \mu \mathrm{m}$ thick silicon micropixel sensor $(256 \times 256=65536$ pixels $)$. As an example, 
Fig. 4 illustrates 2D image of the protons intensity distribution measured by metal TimePix detector with the SLIT collimator installed in front of it.

One may see in Fig. 4 (left) vertical and horizontal narrow regions with zero intensity inside the slits area. Those regions correspond to the image of the grid (metal wires, $100 \mu \mathrm{m}$ diameter) installed in close vicinity to the TimePix readout microchip for provi- ding its metal mode of operation with positive $20 \mathrm{~V}$ applied. Projection of the $2 \mathrm{D}$ data onto $\mathrm{X}$-axis also exhibits the drop of the intensity inside the slit area at position of the grid wires. By passing, we notice that this also illustrates a nice performance of the TimePix detector in reflecting details of the $2 \mathrm{D}$ beam intensity distribution with an accuracy of $55 \mu \mathrm{m}$.
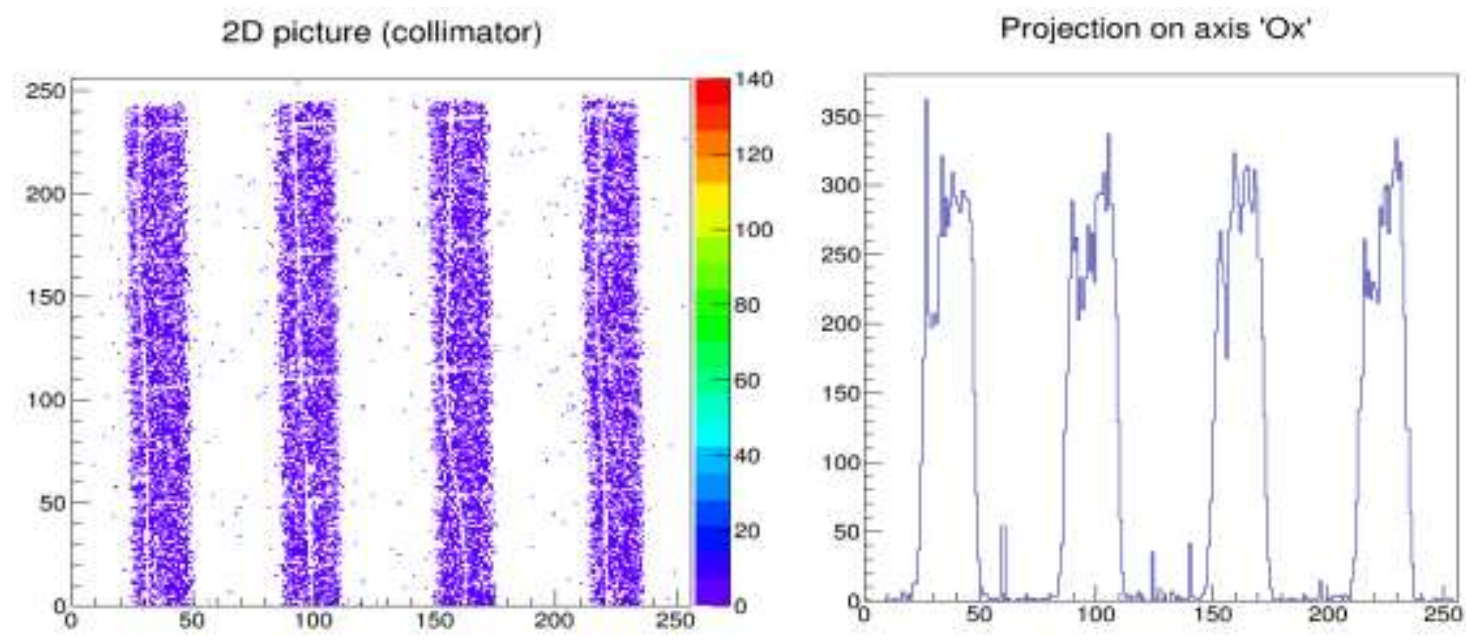

Fig. 4. Left: 2D distribution of the direct proton beam intensity (color scale at the right side) measured by metal TimePix detector (X-and Y-axis - pixel number). SLIT collimator was installed in front of the TimePix (slits are oriented alongside vertical Y-axis). Right: Projection of the data onto horizontal X-axis. See color Figure on journal website.
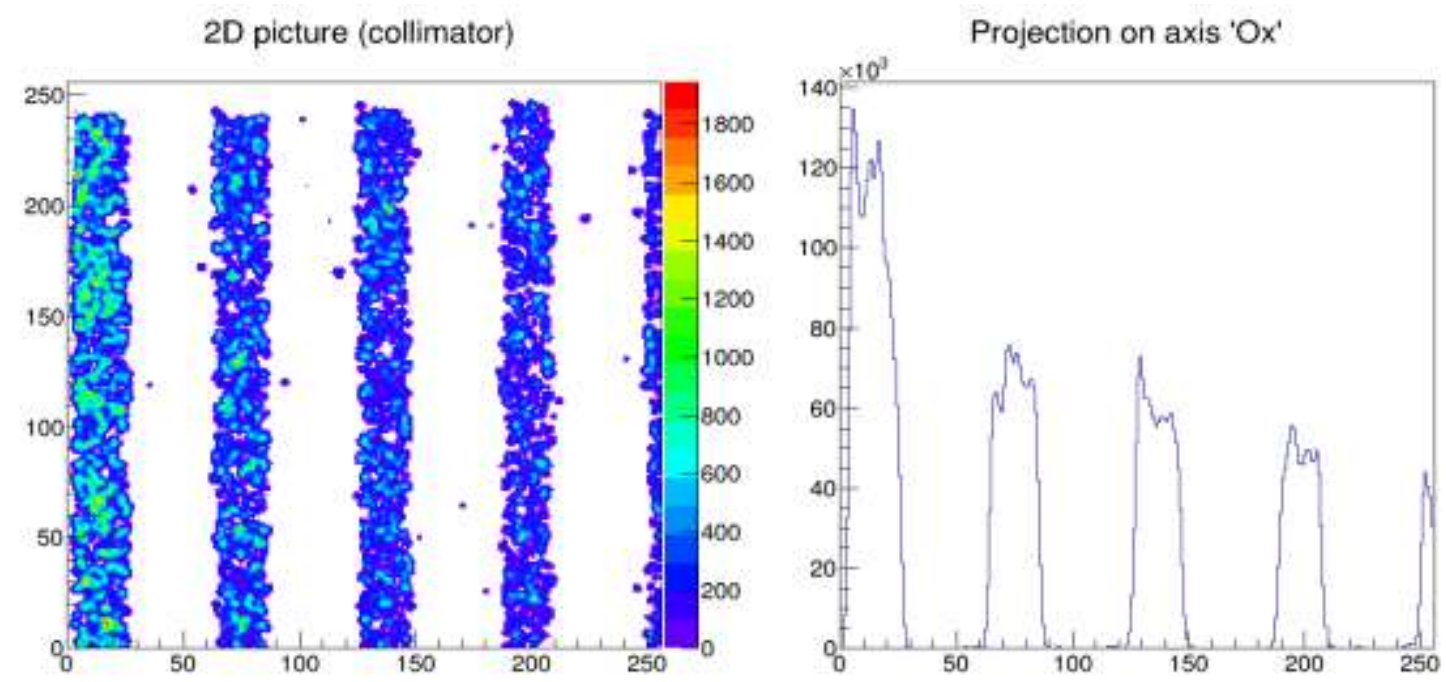

Fig. 5. Left: 2D distribution of the scattered proton intensity (color scale at the right side) measured by the hybrid TimePix detector (X-and Y-axis - pixel number). SLIT collimator was installed in front of the TimePix (slits are oriented alongside vertical Y-axis). Right: Projection of the data onto horizontal X-axis. See color Figure on journal website.

One of the important characteristics of the multichannel detecting system is uniformity of its response. For testing this feature of TimePix we have measured the angular distribution of the protons scattered by the carbon target (Fig. 5) within the TimePix acceptance $\left(41^{\circ}<\Theta<49^{\circ}\right)$ and compared it with the corresponding calculations. From that study we have concluded that the tested sample of the TimePix detector had non-uniform response of its pixels varying within $\pm 15 \%$.

The results obtained with MATRIX collimator installed at the entrance window of the hybrid detector TimePix are illustrated in Fig. 6.

The left part of it represents the two-dimensional distribution of the proton beam intensity over the detector area (intensity scale is shown by the color at the right vertical band), while the right part shows the projection of the intensity distribution on the $\mathrm{X}$-axis. 

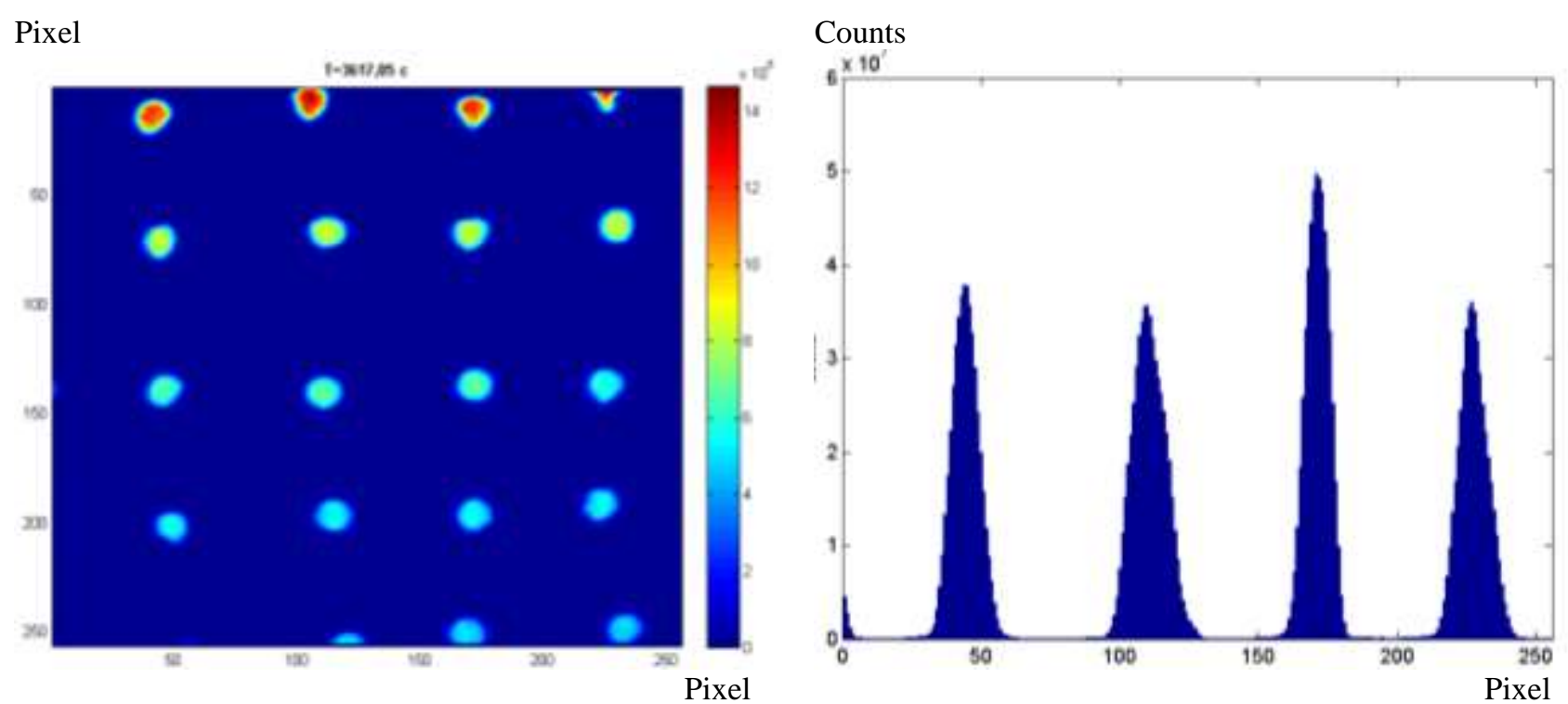

Fig. 6. Left: 2D distribution of the proton beam intensity (color scale at the right side) measured by hybrid TimePix detector (X- and Y-axis - pixel number). MATRIX collimator was installed in front of the TimePix detector. Right: Projection of the data onto X-axis. See color Figure on journal website.

The results illustrated in Figs. 4 - 6 show that micropixel detector TimePix operating in metal or hybrid mode is well suitable for measuring the spatial distribution of the charged particles beams shaped by SLIT or MATRIX collimators for the purpose of the feasibility studies of the spatially fractionated hadron beam radiation therapy.

\section{Summary and outlook}

The results obtained in frames of Monte Carlo simulations as well as in the tests with low energy proton beam indicate a possibility to provide shaping and monitoring of the mini-beam structures for hydrogen, carbon and oxygen ions with the energies relevant for the medical applications (few hundred $\mathrm{MeV} /$ nucleon). Reasonable values of the PVDR and penumbra in dose distribution over the irradiation field were found for the appropriately designed slits and matrix collimators. Collimators made out of brass have advantage in those values. The use of hadrons has the advantage of delivering a uniform dose distribution in the tumor, while healthy tissue benefits from the spatial fractionation of the dose. Studies with relativistic hadron beams should establish the optimum geometry/material factors for collimators designed for the clinical use. Such studies have been recently started at HIT (Heidelberg) and we are going to present their preliminary (positive) results in the forthcoming paper, soon.

This research was partially conducted in the scope of the IDEATE International Associated Laboratory (LIA). We thank MEDIPIX Collaboration and especially M. Campbell, X. Llopart, S. Pospisil, C. Granja for introducing us a chance to use TimePix detectors for these studies. We express our gratitude to the personnel of the KINR Tandem generator for providing stable beam and frank collaboration atmosphere. This work has been supported by the grants of the State Fund For Fundamental Research (project F69/53-2015) and NAS Ukraine (CO-4-1/2015).

\section{REFERENCES}

1. Wilson R. Radiological use of fast protons // Radiology. - 1946. - Vol. 47. - P. 487 - 491.

2. Kraft $G$. Tumor therapy with heavy charged particles // Prog. Part. Nucl. Phys. - 2000. - Vol. 45. - P. S473 S544.

3. Schardt D., Elsasser T., Schulz-Ertner D. Heavy-ion tumor therapy: Physical and radiobiological benefits // Rev. Mod. Phys. - 2010. - Vol. 82. - P. 383 - 425.

4. Slatkin D., Spanne P., Dilmanian F.A. et al. Subacute neu- ropathological effects of microplanar beams of $\mathrm{x}$ rays from a synchrotron wiggler // Proc. Nat. Acad. Sci. U.S.A. - 1995. - Vol. 92. - P. 8783 - 8787.

5. Laissue J.A., Blattmann H., Michiel M.Di. et al. The weanling piglet cerebellum: a surrogate for tolerance to MRT (Microbeam Radiation Therapy) in pediatric neu- ro-oncology // SPIE. - 2001. - Vol. 4508. - P. 65 - 73.

6. Dilmanian F.A., Button T.M., Duc G. Le. et al. Response of rat intracranial 9L gliosarcoma to microbeam radiation therapy // Neuro-Oncology. - 2002. - Vol. 4. - P. 26 - 38.

7. Prezado Y., Fois G. Proton-minibeam radiation therapy: a proof of concept // Med. Phys. - 2013. - Vol. 40. - P. 031712-1-8.

8. Martınez-Rovira I., Fois G., Prezado Y. Dosimetric evaluation of new approaches in GRID therapy using nonconventional radiation sources // Med. Phys. 2015. - Vol. 42. - P. 685 - 693.

9. Devic S., Seuntjens J., Sham E. et al. Precise radiochromic film dosimetry using flat-bed document scanner // Med. Phys. - 2005. - Vol. 32. - P. 2245 - 2253. 
10. Niroomand-Rad A., Blackwell C.R., Coursey B.M. et al. Radiochromic film dosimetry: Recommendations of AAPM Radiation Therapy Committee Task Group 55 // Med. Phys. - 1998. -Vol. 25. - P. 2093 - 2115.

11. Martisıkova M., Jakel O. Dosimetric properties of Gafchromic EBT films in medical carbon beams // Phys. Med. Biol. - 2010. - Vol. 55. - P. 5557 - 5567.

12. Vykydal Z., Jakubek J., Pospisil S. USB interface for Medipix 2 matrix device enabling energy and positionsensitive detection of heavy charged particles // Nucl. Instrum. Methods. Phys. Res. - 2006. - Vol. A563. P. 112 - 118.

13. Lerch M.L.F., Cullen A., Baloglow A.M. et al. Dosimetry of intensive, pulsed synchrotron X-ray microbeams // IEEE Nuclear \& Space Radiation Effects Conference (Quebeck, Canada. July 20 - 24, 2009). PF-3. - P. 23

14. Pugatch V., Campbell M., Chaus A. et al. Metal Micro-detector TimePix imaging synchrotron radiation beams at the ESRF Bio-Medical Beamline ID17 // Nucl. Instrum. Methods. Phys. Res. - 2012. Vol. A682. - P. 8 - 11.

15. Matsufuji Naruhiro, Fukumura Akifumi, Komori Masataka et al. Influence of fragment reaction of relativistic heavy charged particles on heavy-ion radiotherapy // Phys. Med. Biol. - 2003. - Vol. 48. - P. 1605 - 1623.

16. Braunn B., Labalme M., Ban G. et al. Nuclear reaction measurements of $95 \mathrm{MeV} / \mathrm{u}{ }^{12} \mathrm{C}$ interactions on PMMA for hadrontherapy // Nucl. Instrum. Methods. Phys. Res. - 2011. - Vol. B269. - P. 2676 - 2684.

17. Gunzert-Marx K., Iwase H., Schardt D., Simon R.S. Secondary beam fragments produced by $200 \mathrm{MeV} / \mathrm{n}$ ${ }^{12} \mathrm{C}$ ions in water and their dose contributions in carbon ion radiotherapy // New Journal of Physics. 2008. - Vol. 10. - P. 075003.

18. Opalka L., Granja C., Hartmann B. et al. Linear energy transfer and track pattern recognition of secondary radiation generated in hadron therapy beam in a PMMA target // JINST. - 2013. - Vol. 8. - P. C02047.

19. http://www.opengatecollaboration.org/

20. Seravalli E., Robert C., Bauer J. et al. Monte Carlo calculations of positron emitter yields in proton radiotherapy // Phys. Med. Biol. - 2012. - Vol. 57. - P. 1659 $-1673$.

21. Grevillot L., Frisson T., Zahra N. et al. Optimization of GEANT4 settings for proton pencil beam scanning simulations using GATE // Nucl. Instrum. Methods Phys. Res. - 2010. - Vol. B268. - P. 3295 - 3305.

\title{
С. Момот ${ }^{1}$, О. Ковальчук ${ }^{1}$, О. Охріменко ${ }^{1}, ̆_{\text {И. Презадо }}^{2}$, В. Пугач ${ }^{1}$ \\ ${ }^{1}$ Інститут ядерних досліджень НАН Украӥни, Київ, Украӥна \\ 2 Лабораторія обробки зображень і моделювання в нейробіології та онкологї, Орсе, Франція \\ ФОРМУВАННЯ ТА МОНТТОРИНГ МІНІ-ПУЧКОВИХ СТРУКТУР ДЛЯ ПРОСТОРОВО-ФРАКЦІОНОВАНОЇ РАДІАЦІЙНОЇ ТЕРАПІЇ
}

Використовуючи моделювання методом Монте - Карло, оцінено дизайн та ефективність коліматорів для цілей фракціонованої міні-пучкової адронної радіаційної терапії. Розрахунки здійснено для іонних пучків водню, вуглецю та кисню при енергіях, придатних для медичного застосування. Мікропіксельні металеві та гібридні детектори були випробувані для вимірювання розподілу інтенсивності заряджених частинок у багатопучкових структурах, сформованих щілинними або матричними коліматорами, використовуючи низькоенергетичний протонний пучок тандем-генератора ІЯД НАН України (Київ). Отримані результати показали прийнятне функціонування розроблених коліматорів, а також металевих та гібридних мікропіксельних детекторів для вимірювання та візуалізації в реальному часі розподілу інтенсивності протонів в міні-пучкових структурах.

Ключові слова: просторово-фракціонована адронна радіаційна терапія, коліматори пучків, Монте - Карло моделювання розподілу дози, моніторинг просторового розподілу інтенсивності пучків заряджених частинок, мікропіксельні металеві та гібридні детектори.

\author{
Е. Момот ${ }^{1}$, А. Ковальчук ${ }^{1}$, А. Охрименко ${ }^{1}$, И. Презадо ${ }^{2}$, В. Пугач ${ }^{1}$ \\ ${ }^{1}$ Институт ядерных исследований НАН Украины, Киев, Украина \\ 2 Лаборатория обработки изображений и моделирования в нейробиологии и онкологии, Орсе, Франция

\section{ФОРМИРОВАНИЕ И МОНИТОРИНГ МИНИ-ПУЧКОВЫХ СТРУКТУР ДЛЯ ПРОСТРАНСТВЕННО-ФРАКЦИОНИРОВАННОЙ РАДИАЦИОННОЙ ТЕРАПИИ}

Используя моделирование методом Монте - Карло, оценен дизайн и эффективность коллиматоров для целей фракционированной мини-пучковой адронной радиационной терапии. Расчеты выполнены для ионных пучков водорода, углерода и кислорода при енергиях, подходящих для медицинского применения. Микропиксельные металлические и гибридные детекторы были испытаны для измерения распределения интенсивности заряженных частиц в многопучковых структурах, сформированных щелевыми или матричными коллиматорами, используя низкоэнергетический протонный пучок тандем-генератора ИЯИ НАН Украины (Киев). Полученные результаты показали приемлемое функционирование разработанных коллиматоров, а также металлических и гибридных микропиксельных детекторов для измерения и визуализации в реальном времени распределения интенсивности протонов в мини-пучковых структурах.

Ключеые слова: пространственно-фракционированная адронная радиационная терапия, коллиматоры пучков, Монте - Карло моделирование распределения дозы, мониторинг пространственного распределения интенсивности пучков заряженных частиц, микропиксельные металлические и гибридные детекторы. 